\title{
IMPROVEMENT OF LEARNING ACTIVITIES IN SCIENCE LEARNING THE FOURTH GRADE STUDENTS OF STATE ELEMENTARY SCHOOL THROUGH THE MODEL OF PREDICT OBSERVE EXPLAIN (POE)
}

\section{Bety Permata Ningtyas, Hasan Mahfud, Karsono}

Universitas Sebelas Maret

hasanmahfud449@gmail.com

Article History

accepted 09/07/2018

approved 01/08/2018

published 17/09/2018

Keywords

Predict Observe Explain

$(P O E)$, learning activities

\begin{abstract}
This classroom action research was aimed to increase learning activity, improve student's cooperation in learning and self-confidence in students. The object of this research are students class IV SD Negeri Pajang II No.171 Surakarta Academic Year 2017/2018 by applying the model of Predict Observe Explain (POE) in science learning. This research was conducted of three cycles and each cycle consists of four stages of planning, action, observation, and reflection. Data collection techniques are using tests, observations, interviews and documentation. Data validity technique are using content validity and triangulation of technique. Data analysis technique is interactive analysis model which consists of four components, namely data provision, data reduction, data presentation, and conclusion. The result of the research shows that model Predict Observe Explain (POE) can improve learning activities on student class IV of SD Negeri Pajang II No.171 Surakarta in academic year 2017/2018.
\end{abstract}

Social, Humanities, and Education Studies (SHEs): Conference Series https://jurnal.uns.ac.id/shes

p-ISSN 2620-9284 e-ISSN 2620-9292 


\section{PENDAHULUAN}

Kegiatan pembelajaran yang baik merupakan kegiatan pembelajaran yang tidak hanya berhasil meningkatkan nilai akademik siswa, tetapi juga dapat menciptakan interaksi dan aktivitas siswa yang baik selama proses pembelajaran berlangsung. Penentu keberhasilan dalam kegiatan pembelajaran bukan siswa saja, guru juga mempunyai andil besar didalamnya terutama dalam memilih suatu model pembelajaran yang cocok dengan kondisi siswa di kelas. Selain itu, pemerintah juga mengupayakan agar kualitas dalam pendidikan selalu meningkat dan lebih baik melalui penyediaan sarana pendidikan, pembaharuan kurikulum, dan peningkatan kualitas serta keterampilan guru melalui kegiatan penataran. Pendidikan harus sesuai dengan prinsip penyelanggaraan pendidikan, yaitu sebagai suatu proses pemberdayaan peserta didik dengan membangun seluruh aspek potensi yang dimiliki dalam proses pembelajaran. Pembelajaran dalam hal ini berlangsung secara formal untuk masingmasing bidang studi, salah satunya adalah mata pelajaran IPA.

Mata pelajaran IPA membahas tentang gejala-gejala atau fenomena alam secara sistematis berdasarkan hasil percobaan dan pengamatan yang dilakukan oleh manusia. Pembelajaran IPA diarahkan pada kegiatan "mencari tahu" dan "berbuat" sehingga siswa dapat memperoleh pemahaman yang lebih mendalam tentang alam sekitar (Depdiknas, 2004. p.3). Pada dunia pendidikan, mata pelajaran IPA pasti diberikan disemua jenjang pendidikan mulai dari Sekolah Dasar (SD), sampai dengan Perguruan Tinggi (PT). Ilmu Pengetahuan Alam dianggap penting karena berhubungan dengan kehidupan dan peristiwa sehari-hari, oleh karena itu IPA di masukkan dalam kurikulum pendidikan di Indonesia dan menjadi salah satu mata pelajaran wajib di sekolah (Susanto, 2012: 165).

Iskandar (2007:17) mengatakan bahwa IPA dianggap berfaedah bagi suatu bangsa karena kesejahteraan materiil suatu bangsa bergantung pada kemampuan bangsa itu dalam bidang IPA. IPA dianggap sebagai dasar teknologi dan sering dikatakan sebagai tulang punggung pembangunan. Selain itu, IPA juga memberikan kontribusi dalam hal berpikir kritis dan pembentukan kepribadian pada individu. Seiring dengan perkembangan kurikulum pendidikan, salah satu hal yang wajib dipersiapkan adalah peningkatan mutu pembelajaran dengan menciptakan suatu kebermaknaan dalam pembelajaran yang melibatkan siswa dalam penanaman dan peningkatan penguasaan materi pembelajaran. Pembelajaran IPA akan lebih baik dan maksimal jika siswa terlibat dalam memperoleh pengalaman langsung (learning by doing).

Namun kondisi dilapangan menunjukkan bahwa selama proses pembelajaran berlangsung peran guru terlalu dominan dan siswa menjadi pasif karena interaksi di kelas yang hanya satu arah. Siswa lebih banyak mencatat dan mendengarkan apa yang diajarkan oleh guru dan umumnya siswa hanya diam atau tidak merespon guru jika diberikan kesempatan untuk bertanya. Siswa menjadi cepat bosan, malas dan kurang tertarik dalam belajar IPA, bahkan sebagian siswa menganggap pelajaran IPA sebagai momok yang menakutkan. Kejadian seperti ini disebabkan oleh siswa yang tidak pernah terlibat secara langsung dalam kegiatan selama pembelajaran.

Data dari hasil wawancara guru menunjukkan bahwa guru tidak pernah melakukan penilaian pada aktivitas belajar siswa dan hanya menilai pada kognitif siswa saja. Sedangkan, data dari hasil wawancara dengan siswa menunjukkan bahwa siwa: belum pernah melakukan kegiatan eksperimen dalam mata pelajaran IPA dan belum pernah menggunakan media maupun KIT IPA yang dimiliki oleh sekolah.

Kondisi ini diperkuat dengan hasil tes pratindakan pada tanggal 8 Januari 2018, dengan hasil aktivitas belajar siswa dalam kategori kurang. Terkait belum optimalnya pembelajaran IPA khususnya pada aktivitas belajar siswa, maka saya menerapkan model pembelajaran Predict Observe Explain (POE) sebagai salah satu upaya untuk menciptakan pembelajaran yang dapat meningkatkan aktivitas belajar siswa. 
Warsono dan Hariyanto (Puji Rahayu, 2015: 1015) mengatakan bahwa kegiatan dalam strategi POE yang meliputi memprediksi, mengamati, dan menerangkan berguna untuk membentuk struktur kognitif peserta didik menjadi lebih baik, karena kegiatan-kegiatan dalam strategi ini memberikan kesempatan pada peserta didik untuk belajar secara langsung. Kelebihan model pembelajaran POE antara lain: merangsang peserta didik untuk lebih kreatif khususnya dalam mengajukan prediksi, dapat mengurangi verbalisme, proses pembelajaran menjadi lebih menarik sebab peserta didik tidak hanya mendengarkan tetapi terlibat langsung dalam kegiatan eksperimen, siswa mempunyai kesempatan untuk mengeksplorasi keingintahuannya.

\section{METODE}

Penelitian ini dilaksanakan pada siswa kelas IV Sekolah Dasar tahun ajaran 2017/ 2018. Waktu penelitian selama 6 bulan yaitu mulai Oktober 2017 sampai Maret 2018. Data yang dikumpulkan dalam penelitian ini berupa hasil observasi kinerja guru dan aktivitas siswa, hasil wawancara dengan guru dan siswa, hasil tes pratindakan dan hasil tes siklus I, II dan III, serta foto maupun video proses pembelajaran. Sumber data dalam penelitian ini dapat diklasifikasikan menjadi: sumber data primer dan sekunder. Sumber data primer yaitu guru kelas IV, siswa, peristiwa pembelajaran IPA, foto dan video pada proses pembelajaran IPA dengan model pembelajaran POE. Sumber data sekunder yaitu arsip berupa silabus IPA kelas IV semester 2, RPP IPA, hasil atau nilai tes pratindakan, siklus I, siklus II, dan siklus III. Teknik pengumpulan data yang digunakan yaitu observasi, wawancara, tes, dan doku-mentasi. Validitas data yang digunakan yaitu validitas isi, triangulasi sumber dan teknik. Data yang diperoleh dalam penelitian ini dianalisis menggunakan model interaktif Milles dan Huberman. Penelitian ini menggunakan prosedur penelitian yang dilakukan melalui 3 siklus. Setiap siklus terdiri dari empat tahap yaitu perencanaan, tindakan, observasi dan refleksi.

\section{HASIL DAN PEMBAHASAN}

Hasil pengamatan aktivitas siswa diperoleh dari proses pembelajaran IPA menggunakan model pembelajaran Predict Observe Explain (POE) untuk meningkatkan keterampilan mengamati pada siswa kelas IV SD Negeri Pajang II No.171 Surakarta tahun ajaran 2017/2018. Model POE sesuai dengan pendapat Warsono dan Hariyanto (Puji Rahayu, 2015: 1015) memberikan kesempatan pada siswa untuk belajar secara konkret sehingga siswa dapat membangun struktur pemikirannya dengan optimal. Model pembelajaran POE melibatkan siswa secara langsung pembelajaran dan siswa berkesempatan untuk membuktikan prediksi yang telah dibuat melalui kegiatan eksperimen (Indrawati dan Setiawan 2009: 45). Alat yang digunakan untuk melakukan pengamatan pada aktivitas siswa selama proses pembelajaran berupa lembar pengamatan aktivitas siswa. Aspek-aspek yang diamati diantaranya: (a) Keaktifan; (b) Kerjasama; (c) Perhatian; (d) Tanggung Jawab; (e) Percaya Diri.

Penelitian ini dilakukan selama 3 siklus. Masing-masing siklus terdiri dari 2 kali pertemuan dengan alokasi waktu 2 × 35 menit. Materi dalam eksperimen yang dilakukan setiap pertemuan berbeda-beda. Analisis data dari hasil pengamatan aktivitas siswa ketika proses pembelajaran menunjukkan peningkatan secara signifikan pada setiap siklusnya. Adapun skor rata-rata aspek aktivitas siswa selama proses pembelajaran dapat disajikan dalam bentuk tabel sebagai berikut: 
Tabel 1. Perbandingan Nilai Rata-rata Aktivitas Siswa Pratindakan, Siklus I, Siklus II, dan Siklus III

\begin{tabular}{|c|c|c|c|c|c|c|c|c|c|}
\hline \multirow[b]{2}{*}{ No. } & \multirow[b]{2}{*}{ Aspek } & \multicolumn{8}{|c|}{ Nilai Rata-rata } \\
\hline & & $\begin{array}{c}\text { Pra- } \\
\text { tindakan }\end{array}$ & Kategori & $\begin{array}{c}\text { Siklus } \\
\text { I }\end{array}$ & Kategori & $\underset{\text { II }}{\text { Siklus }}$ & Kategori & $\begin{array}{c}\text { Siklus } \\
\text { III }\end{array}$ & Kategori \\
\hline 1 & Keaktifan & 1,53 & Buruk & 1,92 & Kurang & 3,25 & Baik & 3,54 & $\begin{array}{c}\text { Sangat } \\
\text { Baik }\end{array}$ \\
\hline 2 & Kerjasama & 1,50 & Buruk & 1,87 & Kurang & 3,05 & Baik & 3,41 & $\begin{array}{c}\text { Sangat } \\
\text { Baik }\end{array}$ \\
\hline 3 & Perhatian & 1,69 & Kurang & 1,87 & Kurang & 3,04 & Baik & 3,44 & $\begin{array}{c}\text { Sangat } \\
\text { Baik }\end{array}$ \\
\hline 4 & $\begin{array}{c}\text { Tanggung } \\
\text { jawab }\end{array}$ & 1,65 & Kurang & 1,89 & Kurang & 3,01 & Baik & 3,52 & $\begin{array}{c}\text { Sangat } \\
\text { Baik }\end{array}$ \\
\hline 5 & $\begin{array}{c}\text { Percaya } \\
\text { diri }\end{array}$ & 1,65 & Kurang & 1,79 & Kurang & 3,04 & Baik & 3,43 & $\begin{array}{c}\text { Sangat } \\
\text { Baik }\end{array}$ \\
\hline
\end{tabular}

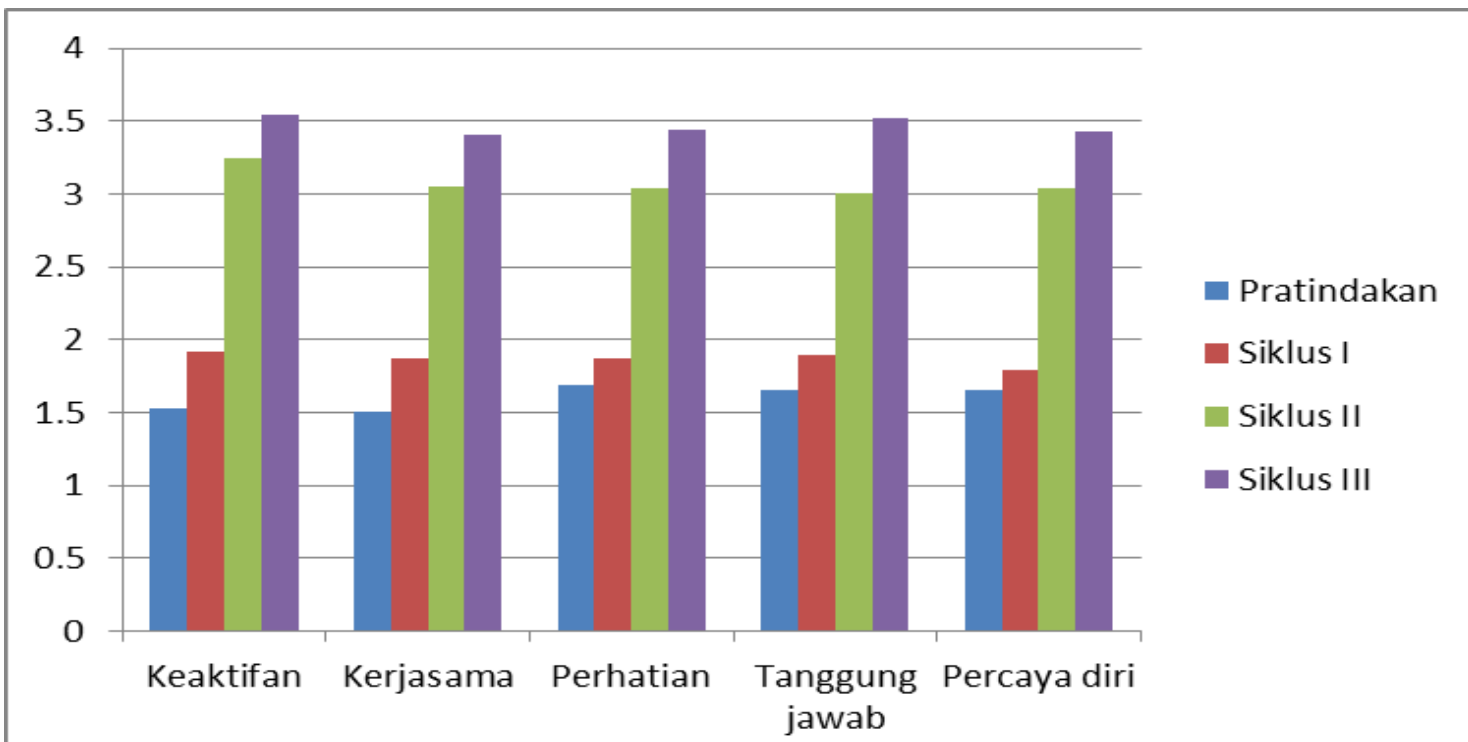

Gambar 1. Hasil Pengamatan Aktivitas Siswa Pratindakan, Siklus I, Siklus II, dan Siklus III

Skor rata-rata aspek dikategorikan menjadi lima kategori yaitu buruk $(1,00-1,60)$; kurang $(1,61-2,20)$; cukup $(2,21-2,80)$; baik $(2,81-3,40)$ dan sangat baik $(3,41-4,00)$. Pada pratindakan, aspek keaktifan memperoleh skor rata-rata 1,53 termasuk kategori "buruk". Pada aspek kerjasama memperoleh skor rata-rata 1,50 termasuk kategori "buruk". Pada aspek perhatian memperoleh skor rata-rata 1,69 termasuk pada kategori "kurang". Pada aspek tanggung jawab memperoleh skor rata-rata 1,65 termasuk kategori "kurang", dan pada aspek percaya diri juga memperoleh skor rata-rata 1,65 termasuk kategori "kurang".

Selanjutnya, dilakukan diskusi dengan guru kelas IV SD N Surakarta untuk mendapatkan pemecahan masalah agar aktivitas siswa meningkat menjadi lebih baik. Sebelum dilaksanakan tindakan siklus I, terlebih dahulu merencanakan pembelajaran dengan menerapkan model POE. Setelah diterapkan tindakan dengan model POE, 
diperoleh skor rata-rata aktivitas siswa mengalami sedikit peningkatan. Pada siklus I, aspek keaktifan memperoleh skor rata-rata 1,92 termasuk kategori "kurang". Pada aspek kerjasama memperoleh skor rata-rata 1,87 termasuk kategori "kurang". Pada aspek perhatian memperoleh skor rata-rata 1,87 termasuk pada kategori "kurang". Pada aspek tanggung jawab memperoleh skor rata-rata 1,89 termasuk kategori "kurang", dan pada aspek percaya diri juga memperoleh skor rata-rata 1,79 termasuk kategori "kurang". Kemudian hasil dari pengamatan aktivitas siswa pada siklus I dilakukan refleksi dengan harapan pada siklus II hasilnya menjadi lebih baik lagi.

Pada siklus II, hasil pengamatan aktivitas siswa aspek keaktifan memperoleh skor rata-rata 3,25 termasuk kategori "baik". Pada aspek kerjasama memperoleh skor rata-rata 3,05 termasuk kategori "baik". Pada aspek perhatian memperoleh skor ratarata 3,04 termasuk pada kategori "baik". Pada aspek tanggung jawab memperoleh skor rata-rata 3,01 termasuk kategori "baik", dan pada aspek percaya diri juga memperoleh skor rata-rata 3,04 termasuk kategori "baik". Hasil pengamatan aktivitas siswa pada siklus II menunjukkan bahwa aktivitas siswa mengalami peningkatan yang cukup signifikan, kemudian dilakukan refleksi dengan harapan aktivitas siswa dapat ditingkatkan secara maksimal.

Pada siklus III, hasil pengamatan aktivitas siswa aspek keaktifan memperoleh skor rata-rata 3,54 termasuk kategori "sangat baik". Pada aspek kerjasama memperoleh skor rata-rata 3,41 termasuk kategori "sangat baik". Pada aspek perhatian memperoleh skor rata-rata 3,44 termasuk pada kategori "sangat baik". Pada aspek tanggung jawab memperoleh skor rata-rata 3,52 termasuk kategori "sangat baik", dan pada aspek percaya diri juga memperoleh skor rata-rata 3,43 termasuk kategori "sangat baik". Hasil pengamatan aktivitas siswa pada siklus III menunjukkan bahwa aktivitas siswa termasuk dalam kategori sangat baik sehingga penelitian dicukupkan pada siklus III karena kriteria kategori yang diharapkan sudah terlampaui.

Pada siklus I ditemui permasalahan berupa kurang kondusifnya suasana kelas dan mayoritas siswa masih bingung saat pelaksanaan eksperimen karena siswa belum pernah melakukan kegiatan eksperimen sebelumnya. Permasalahan pada siklus I ini kemudian diberikan tindak lanjut dan diperbaiki pada siklus II dan III dengan cara memberikan bimbingan kepada siswa yang belum mengerti secara face to face, mengubah posisi duduk, membagi anggota kelompok dengan menggabungkan siswa yang intelegensinya tinggi dan rendah agar dapat saling bekerjasama dan memotivasi satu dengan yang lain, dan pemberian bimbingan kepada siswa pada setiap langkah eksperimen.

Perlakuan yang diberikan selama pembelajaran IPA dengan penerapan model pembelajaran Predict, Observe, Explain (POE) terbukti membawa dampak positif pada siswa selama pembelajaran IPA. Dampak positif dari penerapan model Predict, Observe, Explain (POE) antara lain siswa menjadi lebih aktif, dapat bekerjasama dengan teman dengan baik, perhatian penuh selama proses pembelajaran berlangsung, tanggung jawab dengan tugas yang diberikan oleh guru, dan percaya diri ketika mempresentasikan hasil dari eksperimen maupun ketika menyampaikan pendapat di depan kelas karena penerapan model Predict, Observe, Explain (POE) membuat siswa terlibat langsung dalam membangun pengetahuannya. Hal ini sejalan dengan pendapat Evi Yupani, Garminah, dan Putrini Mahadewi (2013) yang mengutip Joyce (2006) mengatakan bahwa kelebihan dari model pembelajaran POE adalah merangsang siswa menjadi lebih kreatif dan aktif dalam proses pembelajaran, serta siswa lebih bersemangat dalam mengikuti pembelajaran karena terlibat langsung dalam kegiatan eksperimen. Dengan menerapkan model POE (Predict, Observe, Explain) setiap siswa mendapatkan kebebasan untuk memprediksi, mengamati, menganalisis dan menarik kesimpulan sendiri sehingga siswa dilatih terbiasa untuk mencari konsep yang belum diketahui dan memembuktikan rasa ingin tahu siswa terhadap suatu fenomena atau kejadian yang terjadi di dalam kehidupan sehari-hari. 
Pada penelitian ini, langkah penerapan model pembelajaran Predict Observe Explain (POE) sesuai dengan teori yang dikemukakan para ahli dan hanya dilakukan sedikit modifikasi pada pelaksanaan pembelajarannya seperti pemberian bimbingan secara face to face pada siswa yang belum mengerti, mengubah posisi duduk, dan membagi anggota kelompok dengan menggabungkan siswa yang intelegensinya tinggi dan rendah agar dapat saling bekerjasama dan memotivasi satu dengan yang lain, serta penyampaian langkah eksperimen yang harus step by step atau pemberian bimbingan pada setiap langkah eksperimen yang dilakukan.

\section{SIMPULAN}

Berdasarkan hasil penelitian tindakan kelas yang telah dilaksanakan selama tiga siklus dapat disimpulkan bahwa model pembelajaran Predict Observe Explain (POE) dapat meningkatkan aktivitas belajar siswa pada pembelajaran IPA siswa kelas IV Sekolah Dasar Surakarta tahun ajaran 2017/2018.

Berkaitan dengan hasil penelitian, peneliti mengajukan saran 1) bagi guru, hendaknya mempertimbangkan penerapan model dan media pembelajaran inovatif salah satunya model POE karena dapat melatih kerjasama dan rasa percaya diri siswa dalam pembelajaran; 2) bagi sekolah, hendaknya mampu memfasilitasi guru sehingga dapat meningkatkan kualitas pembelajaran di sekolah, 3) bagi peneliti selanjutnya diharapkan lebih memperhatikan dampak pada kualitas pembelajaran juga menambah kajian-kajian pustaka yang lebih lengkap sehingga mampu memperbaiki dan melengkapi kekurangan atau kesalahan yang ada pada penelitan ini.

\section{DAFTAR PUSTAKA}

Miles, M. B. \& Huberman, A.M. (2014). Analisis Data Kualitatif. Terj. Tjejep Rohendi Rohidi. Jakarta: Penerbit Universitas Indonesia (UI-Press).

Depdiknas. (2004). Kurikulum Pendidikan Dasar. Jakarta: Depdiknas.

Iskandar, Srini M. (2001). Pendidikan IImu Pengetahuan Alam. Bandung: CV. Maulana.

Rahayu, Puji., Arif Widiyatmoko., \& Hartono. (2015). Penerapan Strategi POE (PredictObserve-Explain) dengan Metode Learning Journals dalam Pembelajaran IPA untuk Meningkatkan Pemahaman Konsep dan Keterampilan Proses Sains. Universitas Negeri Semarang.

Susanto, Ahmad. (2013). Teori Belajar \& Pembelajaran di Sekolah Dasar. Jakarta: Prenadamedia Group.

Yupani, Evi., Garminah., \& Putrini Mahadewi. (2012). Pengaruh Model Pembelajaran Predict-Observe-Explain (POE) berbantuan Materi Bermuatan Kearifan Lokal terhadap Hasil Belajar IPA Siswa Kelas IV. Jurnal PGSD, Jurusan TP, FIP Universitas Pendidikan Ganesha Singaraja, Indonesia. 